\author{
The Implications U-Boat Commerce Warfare In World Wars ${ }^{1}$ \\ Bülent Yazıci ${ }^{2}$ \\ Izmir University of Economics, Ph.D. Student, Political Science, and International \\ Relations, Izmir, Turkey \\ Received- Accepted: 27.05.2019-17.06.2019 \\ Research Article
}

\begin{abstract}
The development of weapon technologies had reached remarkable momentum with the industrial age. One of these new weapons systems is the submarines. The navies were originally planned to be used for coastal defense purposes only because of their insufficient capacities. But submarines have been transformed into a serious striking force by increasing their capacities and range thanks to generators operating with steel, battery, and gasoline. In the First World War, the Germans used the submarines for the first time in order to attack the enemy logistic convoys in the high seas instead of the coastal protection mission. In 1917, this new war concept would force the United Kingdom to surrender, which would almost succeed. At this point, the comparative analysis of the German Navy's success with the U-Boats in the first and second world wars will be examined in this study.
\end{abstract}

Keywords: Submarine, U-Boat, German Navy, Royal Navy, Maritime Commercial War, Naval Warfare.

\title{
İki Dünya Savaşında U Sınıfi Denizaltı Ticari Savaşı Çıkarımları
}

\section{$\ddot{O} z$}

Endüstriyel çağın başlamasıyla birlikte silah teknolojilerinin gelişimi önemli bir ivmeye ulaşmıştır. Bu yeni silah sistemlerinden biri de kuşkusuz denizaltılardır. Donanmalar denizaltıları ilk olarak yetersiz kapasitelerinden dolayı ancak kıyı savunma görevinde kullanılmak üzere planlamışlardır. Fakat Denizaltılar, zamanla çelik, batarya ve benzin ile çalşan jeneratörler sayesinde kapasiteleri ve menzilleri artırlarak ciddi bir vurucu güç haline getirilmiştir. Birinci Dünya Savaşında, Almanlar, denizaltıların kullanım konseptinde değişiklik yaparak, ilk defa bu silah sistemlerini kıyı koruma görevi yerine açık denizlerde düşman lojistik konvoylarına saldırma amacıyla kullanmışlardır. 1917 yilında bu yeni savaş konsepti neredeyse amacına ulaşacak Birleşik Krallığ teslim olmaya zorlayacaktı. İkinci Dünya Savaşında da aynı savaş konseptini belirlemesine rağmen Alman denizaltıları bir önceki savaşta elde ettiği başaryya ulaşamamıștr. İşte bu noktada Alman Donanmasının hem birinci hem de ikinci dünya savaşında U-Boat'ları ile yürüttïğü ticari savaşın arzu edilen hedefe ulaşmada ne kadar başarlı olduğunu, alınan kararların ve teknolojik gelişmelerin bu çalışmada karşılaştırmalı analiz yapılarak incelenecektir.

Anahtar Kelimeler: Denizalt, U-Boat, Alman Donanması, Kraliyet Donanması, Deniz Ticari Savaşı, Deniz Savaşı

\footnotetext{
${ }^{1}$ This article is analyzed by two reviewers and it is screened for the resembalance rate by the editor. (Bu makale iki hakem tarafindan incelenmiş ve editör tarafindan benzerlik oranı taramasından geçirilmiştir)

${ }^{2}$ bulent.yazici@std.izmirekonomi.edu.tr, ORCID 0000-0002-2175-2557.
} 


\section{Introduction}

The wars are the inevitable reality of human history. The braveries of the heroes, constancy of soldiers and wisdom of the commanders have been more mentioned in popular history. However, in military history, some weapon systems have caused serious military and political consequences. Historians have analyzed the effects of these weapons on the fate of the war and then on world politics. So, the weapon technologies have also been one of the crucial determinants for war history. As Swiss military strategist, Antoine-Henri Jomini emphasized that "the superiority of armament may increase the chances of success in war, but it does not itself win battles". Undoubtedly, the discipline and operational concept of weapons are other significant factors for affecting the victory of wars. The effective usage of pike by the Macedonian phalanx, the disabling of the indestructible fortification wall by ottoman guns, the emergence of the first example of the seaborne empires through the caravels are the significant instances of weapon systems that could change the fate of the human history (Parker, 1995). Moreover, the development of the atomic bomb, at the end of the Second World War these bombs dropped into two Japanese cities, suddenly changed the balance of World political power. Therefore, a new atomic age has begun. The whole world is shaped according to the politics of the countries that own these weapons.

"Alfred Thayer Mahan who was significant navy strategist put forwards famous naval doctrine depends on naval supremacy. According to the $19^{\text {th }}$-century doctrine, a country should control the strategic seas by adequate power and convenient way for world supremacy. The application of this doctrine in the seas where the strategic raw materials such as coal, iron, and oil on the commercial route are more important than trying to destroy the warring navies."

In this regard, Germany followed the Mahan strategy to restrain the Royal Navy access to their world market and sources of supply; however, it was not the destruction of the British battle fleet. So, Submarine had theoretically emerged to deny access to the British Navy to the use of the seas (Ambrose \& King, 1970). This study will focus on a submarine that the new weapons of the navies that were used effectively at the beginning of the 20th century. In this study, I analyzed the comparative perspective of the military and political results of the campaigns of German submarines (U-Boat) in the two World Wars. My research question is "How results were the commerce warfare of German U-Boats during the two World Wars?"

\section{Pre-War Period}

The unification of Germany and its rapid industrialization is one of the great impacts on political history during the nineteenth century. Unfortunately, this incident caused the growing trade and military rivalry between Great Britain and Germany. By the beginning of the twentieth century, While Germany was the first in steel and chemical production in the world; it lacked a source of raw materials because it did not have enough colonies such as its rivals England and France. Therefore, Germany Empire needed a powerful fleet to challenge France and the Royal Navy in order to obtain a new colony (Halpern, 1994, s. 35-36) So, The German Empire increased its military spending by quadrupled between 1874 and 1890. Indeed, Germany had never been a naval power, but in 
1897 the Reichstag allocated huge funds for the expansion of the Germany Navy over the next six years (Merriman, 2004, s. 951). It should be noted again The Germans were in a position to dominate the Europe Continent both land forces and economically, but, Germany required the powerful Navy to challenge the British at sea to achieve its objective. (Halpern, 1994, s. 37)

Admiral Alfred von Tirpitz, head of the German Imperial Naval Office - RMA from 1897 to 1916, governed RMA policy. In 1894, Tirpitz set forth the military doctrine that the direct challenge to Great Britain through the enormous increase in German naval power based on battleships. According to Tirpitz, this doctrine was the only way to seize supremacy on the high seas against the Royal Navy. On the contrary, German naval theorists like Karl Garter, Kurt von Maltzahn, and Lothar Persius supported strategies based upon commerce raiding, which seemed the best possible way to challenge Great Britain Navy instead of high sea battle (Weir, 1984, s. 174-190).

Another problem is that the German navy faced a difficult geographic problem when examining the prospect of a maritime war against Great Britain. The British Isles have been compared to the stopper in a bottle, hindering Germany's access to the open sea. So, Germany had no option but to develop a powerful battle fleet, one strong enough to deter the British. If this strategy reaches its goal, a battle fleet could also increase Germany's value as a potential ally (Elleman \& Payne, 2013, s. 351).

Initially, the Germany Navy had no interested in submarine development and thought it had not been in any strategic future war plans. Germany and its allies including Portugal and Turkey had no plans to procure to these new underwater vessels to their fleets (Weir, 1984). However, in a few years with some technological development, the submarines came to forward to German Navy Staff(Edwyn, 1972, s. 19). Thanks to the success of the 1906 and 1908 supplementary naval laws the pace of Germany's U-boat program quickened. The RMA began eleven boats during this period and money for research and development was less scarce. The German Navy may have been cautious but, by 1910, their U-boats could cross the North Sea, carry out a patrol, and then return to Germany without refueling (Weir, 1984, s. 181).

Without going into the details of the subject, I should draw your attention to why the purpose of this submarine would be used in the naval battlefield. Basically, Submarines have been employed in two basic kinds of naval strategy. These are conventional and unconventional. The conventional submarine naval strategy means that the strategy of conventional sea warfare is the military strategy applied to the establishment of supremacy in the seas against the enemy navy. However, the objective of the unconventional submarine naval strategy is the enemy state rather than its armed forces. Moreover, one way of the unconventional submarine warfare is maritime commerce war. The aim of the commercial war is to prevent the supply of raw materials and stuff, such as weapons, foods, raw materials, from the host country from abroad and to force it to be withdrawn or surrendered by preventing communication with abroad. This type of strategy was attempted with submarines in two world wars. (Lautenschlager, Winter, 1986-1987, s. 94-140). 
Indeed, the submarine actually became an effective warship in 1910 with new technological development such as toughened hull and battery technology. This first submarine as U-9 commissioned for service in 1910, it was an assigned for coastal patrol because of limited range and capacity. Finally, the German Navy introduced the U-19 Submarine with new diesel engines in 1913. It would have more range, capacity and functional for high sea naval operation (Lautenschlager, Winter, 1986-1987, s. 11). Despite significant technological advances in the submarines, the German Navy Chiefs were skeptical about submarines to engage and destroy the Imperial High Seas Fleet (Massie, 2003, s. 47).

\section{First World War}

Just before the start of World War I, "Risk Theory" by Admiral Tirpitz was not successful. Since, the dreadnought, the most powerful war machine in the sea at that time, could not be produced enough to achieve a certain victory on the high seas against the Royal Navy. In the meantime, with the outbreak of the war, the U-Boat quickly proved to the Germans as an awesome destructive power, and remarkable offensive capability (Tarrant, 1989). First great successful mission of the U-Boat happened on the 22nd of September 1914, a U-9, commanded by Weddigen, encountered three British Armored cruisers. Within an hour, U-9 sent to the bottom 3 cruisers; sixty-two officers and 1,397 men went down with them. This success was enough to change the view of the German Staff against the Submarines. At the beginning of the war, Germany had twenty-eight U-boats in service and nineteen under construction, but immediately after mobilization began, another eighteen boats were ordered and others quickly followed. (Edwyn, 1972, s. 36-37).

However, the war in Europe did not go as planned by the German Staff. German Staff's Schlieffen Plan, which predicted that the western front would fall in a short time, had collapsed. For this reason, the German Staff would need new methods and strategic decisions for the achievement of their purposes. Moreover, the British blockade was beginning to make its presence felt in Germany. As mentioned above that German Naval High Command noticed the successes of $U-9$ and U-Boat's extended potential impact on the course of the war (Art, 1973, s. 21-22). By the way, the British Navy Staff had underestimated the potential impacts of U-Boat as a serious threat. Another historical example is that a single U-Boat, $U-18$, sailed into the heart of the British home fleet at Scapa Flow, Scotland, and narrowly missed destroying up to six of its dreadnoughts, which had left several hours for the mission (Tarrant, 1989, s. 11).

In the first years of the war, the submarine attack did not give the desired effect. Of course, the insufficiency of the number of submarines in the German Navy is the significant factor. It is also another factor that the rule of conflict law was applied by German submarines to commercial and logistic ships to the British mainland. Because the submarines first come to the surface of the water, the ship wants to surrender, if surrendered after the crew boarded the ship dipped the ship. The risk for German submarines was increased after the merchant ships developed their own defense systems and escorted other warships. For this reason, the existing rules would be ignored and without warning, the ships would be sunk. On the other hand, the accidental sinking of neutral shipping, especially American, could cause huge diplomatic strains because of this decision (Tarrant, 1989, s. 12-13). 
Upon the success of the U-Boats; Britain is surrounded by German submarines and is intended to cause trouble for the logistics of the country. Briefly, with this strategy, the British Empire would be forced to surrender (Edwyn, 1972, s. 81). During the first six months, the German Submarines sunk only 10 merchant ships totaling about 20,000 tons. As more U-boats were built and they went to sea with 8 to 12 torpedoes, the monthly rate of sunk of merchant ships began to rise. In September 1916, the monthly total went above 200,000 tons for the first time.

In February 1917, German U-boats were able to sustain an average of 614,000 tons sunk per month, and this rate was causing serious problems on the British island. However, the German General Staff had also made the mistake of calculating. (Lautenschlager, Winter, 1986-1987, s. 111-112) Germany was on the verge of the battle won in 1917. Although the western front seems to be a stalemate, in eastern front Germany was successful because of the eliminating of Russia through successfully blockade. In the Atlantic, Germany was blockading Britain, with U-boat commercial war. Statistically, one of every four ships of Britain was sunk. In response to this Britain could compensate one ship for each 10 sunken (Ambrose \& King, 1970). The German high command calculated that Britain would be knocked out of the war if 600,000 tons of British shipping were sunk every month for six months in 1917. But the requirement for victory should have been reached the rate of about 900,000 tons per month. Even if the German Navy had 172 U-boats, Imperial Germany's could not accomplish this objective. As a result, the 320 U-boats that sortied during the war, 178 were lost. (Koerver, 2010, s. 21-22). Due to high numbers of loss, Lloyd George ordered the Royal Navy to form of the convoy system. The order caused the slowly decreasing of the loss numbers of the ships. After the convoy system, over 80 percent of the shipping reached Britain peacefully by 1918. Over time, Less than 1 percent of ships in convoy was lost. In addition to decreasing the number of loss, Britain could compensate to build new ships than a number of losing ships. Therefore, the convoy system provided to the survival of England (Ambrose \& King, 1970)

Another incident involving the U-Boats is the sunk of the Lusitania transatlantic. Lusitania, transatlantic, was sunk by a German U-boat on May 7, 1915. This attack caused the loss of 1,198 passenger's life. Therefore, Kaiser abandoned the unrestricted submarine warfare against the enemy until February 1917 (Parker, 1995). Indeed the incident caused indirectly to the entry of the United States into World War I. Before incident, America was equally resentful towards Britain and Germany for their actions revolving around America's merchant fleet. However, this incident would cause a diplomatic crisis and American public opinion turned against Germany (Massie, 2003, s. 535).

Prior to the First World War, the German General Staff gave more importance to the production of warships such as large-tonnage dreadnoughts. With the war's failure to go as planned, he found strategic importance that the U-boats had a significant impact by using it in the maritime commercial war. Almost in 1917, this strategic decision would cause Britain to surrender. If the German Empire had given enough importance to the U-Boat fleet before the war, the fate of the war would be very different. As a result, in 1917, as much as the Uboats could not cope with the US participation in the war, the logistical support and the troops were sent to the 
Allies (Parker, 1995).

\section{Second World War}

Before the Second World War, the German General Staff had determined the number of U-Boats to defend the Baltic Sea against the Soviet Navy, which they considered a possible threat during the war, according to the war plan. Actually, Germany could not assess that the United Kingdom could intervene in the Second World War. At the beginning of the Second World War, there were 56 submarines in the hands of the German Navy. 46 percent of them were ready for the expedition missions. The U-boats' mission concept changed with the United Kingdom's participation in the war. (Assmann, 1950, s. 664). Thereby, Germany launched its second commerce warfare with the submarines against the British Empire in the early 1940 summer. The second U-boat expedition took place in five stages. The main objective of the German Naval Staff is to have as many submarines as possible, a minimum loss and a maximum sinking of tonnage, called "tonnage warfare, as much as it cannot compensate for Britain. But it will be seen that this will not reach its goal (Lautenschlager, Winter, 1986-1987, s. 114).

At the beginning of World War II, the United States did not participate in the World War. 7 December 1941 after the attack on Pearl Harbor, the United States would declare war on Germany, Japan, and Italy. In this period, Germany did not want the United States to join the war against the Allies. In this respect, the German Navy was careful in Atlantic navy expeditions. Nevertheless, like in the First World War, accidents have taken place. The German submarines sunk the US merchant ship, the Greety, the Kearney and the Reuben James. This situation increased the political tension between the USA and Germany. The US declared war on Germany, even though it was the direct attack of the Japanese Navy (Assmann, 1950, s. 663).

The British Empire and the United States alone had 33 million tons of shipping in 1939, and during the war, they would build another 42 million tons. In the first phase, the German submarines were first assigned to support the Norwegian occupation when the war began. After the occupation, by order of Admiral Donitz, he joined the Commerce Warfare and caused a loss of 200,000 tons per month on average British ships. In the second phase of the commerce campaign, beginning in April 1941, the number of German submarines increased to about 200. However, during this period, the United Kingdom gained the cipher keys of U-Boat communications with HQ. So, the rising tide of ship loses of Britain was relatively dropped in the first half of 1941. In reply, the Germans developed a new complexity encoding system at the end of 1941 (Parker, 1995). With Britain's loss rate increases, the most important development began six months later, when the United States joined the war in the third phase. In the concept of tonnage warfare, this was an opportunity to attack unprotected shipping with the little initial risk of losses. So, with the sinking of American merchants ships, the rate of sinking rose rapidly. In November 1942, the quantity of U-boat strength rose from 284 to 379; therefore, German submarines sank approximately 500,000 tons of shipping per month in the Atlantic during this period. (Lautenschlager, Winter, 1986-1987, s. 115-116).

In the fourth phase, the German Navy has increased the number of sailors up to 400 by January 1943. The wolf pack tactics which was put into practice by Admiral Donitz to the Allied logistic convoys the offensive 
tactic caused serious losses. In this period, the losses of the allies reached a peak of 743,000 tons per month. In the fifth and last phase, In August 1943, when Germany understood that it could not defeat allies, the submarine fleets were given the mission to protect the coast in order to prevent the occupation attempt on the European continent. In this period, the average monthly casualties of the German submarines to the allies decreased to 100,000 tons (Lautenschlager, Winter, 1986-1987, s. 117-118).

The one of the significant reason of the failure of the German U-Boat attacks, the main problem was that the German Submarine Commerce Warfare lost an average of 250,000 tones to allies during the war, but the Allies compensated these losses with 1,000,000 tones. As much as Germany increases the number of submarines, it seems impossible to reach this level. Germany's failure to foresee the industrial capacity of the Allies in the Second World War was one of the biggest strategic mistakes they made. (Assmann, 1950, s. 669). The second crucial reason was that despite the opposition of Admiral Donitz, Hitler ordered that part of the U-Boat fleet be sent to Norway in order to defend against a possible invasion, while another part assigned against the ships of the allied forces in the Mediterranean. As a result, Admiral Donitz had lost the flexibility to make decisions on its fleet and this circumstance increased the potential risks further. Finally, this situation prevented the German Navy Staff from seeing the big picture (Parker, 1995).

In another viewpoint, the successful anti-submarine warfare (ASW) methods applied by the Allies and the English, furthermore, password crackers of Britain deciphered the German submarine communication is also a serious factor increasing the number of loss of German U-Boats. Therefore, The Germans were struggling to compensate both the trained manpower and the corresponding tonnage. 940 of these submarines participated in the Atlantic Commerce Warfare, and 784 were sunk by the Allied Forces. It should be noted that the Germans did not make the second Atlantic expedition as long as it threatened Britain in 1917. In summary, German submarines were able to sink only 14 million tons of the total 84 million tons of shipbuilding that the Allies had reached during the war. This corresponds to a total of 17 percent (Lautenschlager, Winter, 1986-1987, s. 119).

A military operation should focus on the purpose, not only the destruction of the target. So, the strategy, along with many parameters, affects the level of combatant force, the manner in which the force is used, the maneuver to be performed, the deception, and the selection of the center of gravity. The level of operation determines the context in which tactical activities are to be carried out. In this regard, indecisive and unsteady tactical activities may seem successful in the short term, so the half-baked strategy with unsynchronized tactical activities causes unnecessary loss, even military defeat (Topuz, 2016, s. 18). In respect of the issue, the most crucial strategic shortsightedness of Admiral Donitz is that the U-boat Commerce Warfare could cause serious logistical difficulties for the allies, just as in the First World War. However, The German Navy assigned some Uboats to keep Royal Navy away from the German coast, and block the western shores of the Baltic Sea to prevent the allies to lend assistance for the Soviet Union (Topuz, 2016, s. 76) In fact, rather than concentrating the U-boat fleet on the commerce warfare, they should have been assigned to support of German Navy fleet to ensure the dominance of Mediterranean Sea. Particularly in North Africa Operations, the German Army suffered severe 
weakness due to the increasing logistic requirements that could not be met efficiently and effectively due to the effectiveness of the Royal Navy in the Mediterranean.

\section{Conclusion}

$\begin{array}{lcc} & \begin{array}{c}\text { Germany vs. Great Brain } \\ \text { 1914-1918 }\end{array} & \begin{array}{c}\text { Germany vs. Great Brain } \\ \mathbf{1 9 3 9 - 1 9 4 5}\end{array} \\ \text { Submarines } & & \\ \text { In Commission } & 374 & 1.171 \\ \text { Sortied } & 320 & 940 \\ \text { Lost } & 178 & 784 \\ \text { Lost to ASW } & 134 & 593 \\ \text { Total Sorties } & 3.274 & ? \\ \text { Merchant Shipping } & & \\ \text { Tonnage Available } & & \\ \text { (millions) } & & \\ \text { Before War } & 43,1 & 41,4 \\ \text { Built during War } & 10,8 & 42,5 \\ \text { Captured } & 2,4 & 0,7 \\ \text { TOTAL } & 56,3 & 84,6 \\ \text { Tonnage sunk (millions) } & & \\ \text { by Submarines } & 11,2 & 14,7 \\ \text { by Mines } & 1,1 & 1,4 \\ \text { by Surface Warships } & 0,6 & 1,6 \\ \text { by Aircraft } & - & 2,9 \\ \text { TOTAL } & 12,9 & 20,6 \\ \text { Percentage Losses } & & \\ \text { Submarine Force } & 47,6 & 67,0 \\ \text { Merchant Fleet to Sub } & 19,9 & 17,4 \\ & & \\ & & \\ & \text { Table-1 Submarine Campaigns In Two World Wars } & \\ & & \\ & & \end{array}$

In the two World Wars, the submarine warfare carried out by the German Navy in the Atlantic Ocean is compared in terms of military and political implications against Britain and then the allied countries. Initially, During the First World War, the German Navy insisted to carry out the concept of commerce warfare from the beginning to the end. Even with the German Navy U-boat attacks in 1917, leaving Britain in a very difficult position, very close to reaching its goal. As can be seen in the table above, in the first world war German submarines sunk the 11,2 million tons of (the total 56,3 million tons) ships of Great Britain through submarine attacks. by contrast, 178 of the 320 U-Boats that the German Navy had during the war were sunk by Britain. In other words, the German navy lost 56 percent of the submarines. If Tirpitz did not insist to the "risk fleet theory" and, provided more production of U-boats as planned maritime commercial warfare instead of coastal defense

\footnotetext{
${ }^{3}$ Tarrant, V.E., 1989. The U-Boat Offensive 1914-1945. Annapolis: US Naval Institute Press
} 
before the First World War, the fate of Great War might be different.

Undoubtedly, the most important turning point of the submarine warfare carried out by the German Navy is the sinking of the RMS Lusitania. This incident led to the return of the American public, which was neutral at the beginning of the war, against Germany. Although there was no direct attack against the US military, it joined the war in 1917 in favor of the Allies.

In the Second World War, German submarines did not succeed as much as the First World War, despite the serious technological advancements and the considerable numbers in the German Navy. One of the significant reason for the unsuccessful second commerce warfare of the German Navy is the lack of a stable, insistent, and consistent submarine warfare strategy. German U-Boats had been used in different missions such as the Norwegian invasion, Atlantic attacks, and European continent defense. This decision had prevented the efficient and effective use of the total U-boat power. So, 784 of the total 940 submarines participating in the Atlantic operation of the German Navy were sunk by Allied forces. In other words, they have lost 84.6 percent of the total number in which this is a very large figure. Apart from the strategic decisions behind this failure, the tactics and technologies developed by the allied forces for the submarine defense warfare were numerous.

Politically, the German U-boats sank a few American merchant ships without the US being involved in the war, but the US government and the public already had a decisive judgment against Nazi Germany. Japan's alliance with Germany and the Japanese attack on Pearl Harbor is another factor that has caused the United States to declare war directly against Germany. One possibility is that if the German Naval Staff had adopted the strategy of Admiral Tirpitz at the beginning of the First World War, both wars destiny could have been different.

Consequently, although the Atlantic Commerce Warfare carried out by the Germans through U-boats in both World Wars failed because of wrong, unstable and indecisive war strategy and miscalculation. because indecisive and volatile tactical objectives seemed favorable and successful in the short term, in the course of events the half-baked strategy with shortsighted tactical activities caused significant loss of U-boat fleet and marines. Though the unsuccessful U-Boat campaigns during the World Wars, many World Navies launched the procurement and production program to constitute their submarine fleet after World War II because of submarine effectiveness and deterrence. Since commerce warfare strategy has been adopted by many states as a crucial strategy that can lead to logistic outsourcing of hostile countries, which can lead to loss of the war. 


\section{References}

[1] Ambrose, S. E., \& King, E. J. (1970). Seapower in World Wars I and II., Naval War College Review, 40(7), 26-40.

[2] Art, R. J. (1973). The Influence Of Foreign Policy On Seapower: New Weapons And Weltpolitik In Wilhelminian Germany, Beverly Hills: Sage Publications.

[3] Assmann, K. (1950, July). Why U-Boat Warfare Failed, Foreign Affairs, 659-670.

[4] Edwyn, G. (1972). The Killing Time: The U-Boat War, 1914-18, London: Charles Scribner's Sons.

[5] Elleman, B. A., \& Payne, C. M. (2013). Commerce Raiding: Historical Case Studies, 1755-2009, New Port: Naval War College Press.

[6] Halpern, P. G. (1994). The Naval Balance in 1914. Annapolis, Maryland: Naval Institute Press.

[7] Koerver, H. J. (2010). German Submarine Warfare 1914-1918 in the Eyes of British Intelligence, Seiten: LIS Reinisch.

[8] Lautenschlager, K. (Winter, 1986-1987). The Submarine in Naval Warfare, 1901-2001, International Security, 11(3), 94-140.

[9] Massie, R. K. (2003). Castles of Steel: Britain, Germany, and the Winning of the Great War at Sea, New York: Random House.

[10]Merriman, J. M. (2004). In a History of Modern Europe: Renaissance to the Present, New York: W. W. Norton.

[11]Parker, G. (1995). The Cambridge Illustrated History of Warfare, Cambridge: Cambridge University Press.

[12]Tarrant, V. E. (1989). The U-Boat Offensive 1914-1945, Annapolis: US Naval Institute Press.

[13]Topuz, S. (2016). Modern Deniz Harbini ve Denizler İçin Mücadeleyi Anlamak, Ankara: Alibi Yayıncllk.

[14]Weir, G. E. (1984). Tirpitz, Technology and Building U-Boats, 1897-1916, The International History Review, 6(2), 174-190. 